\title{
A multifunctional DNA-binding protein that promotes the formation of serum response factor/homeodomain complexes: identity to TFII-I
}

\author{
Dorre A. Grueneberg ${ }^{1,2,4,5}$ R. William Henry, ${ }^{2}$ Andrew Brauer, ${ }^{1}$ Carl D. Novina, ${ }^{3}$ \\ Venugopalan Cheriyath, ${ }^{3}$ Ananda L. Roy, ${ }^{3}$ and Michael Gilman ${ }^{1,2,4}$ \\ ${ }^{1}$ ARIAD Pharmaceuticals, Cambridge, Massachusetts 02139 USA; ${ }^{2}$ Cold Spring Harbor Laboratory, Cold Spring Harbor, N ew \\ York 11724 USA; ${ }^{3}$ Tufts University School of Medicine, Department of Pathology and Division of Immunology, \\ Boston, M assachusetts 02111 USA
}

The human homeodomain protein Phoxl interacts functionally with serum response factor (SRF) to impart serum responsive transcriptional activity to SRF-binding sites in a HeLa cell cotransfection assay. However, stable temary complexes composed of SRF, Phoxl, and DNA, which presumably mediate the transcriptional effects of Phoxl in vivo, have not been observed in vitro. Here, we report the identification, purification, and molecular cloning of a human protein that promotes the formation of stable higher-order complexes of SRF and Phoxl. We show that this protein, termed SPIN, interacts with SRF and Phoxl in vitro and in vivo. Furthermore, SPIN binds specifically to multiple sequences in the c-fos promoter and interacts cooperatively with Phoxl to promote serum-inducible transcription of a reporter gene driven by the c-fos serum response element (SRE). SPIN is identical to the initiator-binding protein TFII-I. Consistent with this hypothesis, SPIN exhibits modest affinity for a characterized initiator sequence in vitro. We propose that this multifunctional protein coordinates the formation of an active promoter complex at the c-fos gene, including the linkage of specific signal responsive activator complexes to the general transcription machinery.

[Key Words: Homeodomain; serum response factor; transcription; c-fos; TFII-I]

Received July 2, 1997; revised version accepted August 12, 1997.

Interactions between the MADS box protein serum response factor (SRF) and homeodomain proteins may serve as a model for understanding how cell type-specific genes are activated in response to generic signals. We have shown previously that SRF interacts with the human homeodomain protein Phoxl and that this interaction imparts to reporter genes the potential to respond to extracellular signals by facilitating the binding of SRF and its signal responsive accessory protein Elk-1 to the serum response element (SRE) derived from the c-fos gene (Grueneberg et al. 1992, 1995). Furthermore, Phox1 facilitates the binding of SRF to a subset of variant SRE sequences that may represent imperfect SREs found in the promoters of cell type-specific genes (Grueneberg et al. 1995). This interaction suggests that homeodomain proteins can direct signal transduction pathways to cell type-specific genes and provides a possible mechanistic

${ }^{4}$ Present address: ARIAD Pharmaceuticals, Cambridge, Massachusetts 02139 USA.

${ }^{5}$ Corresponding author.

E-MAIL gruenebe@ariad.com; FAX (617) 494-8144. connection between signal transduction and cell identity.

The Phoxl protein was originally identified in a yeast selection for its ability to interact with the yeast SRF homolog MCMI to activate a cell type-specific and pheromone-inducible reporter gene (Grueneberg et al. 1992). The Phox1 cDN A contained a homeobox related most closely to that of the Drosophila paired gene. In a mobility shift assay using Escherichia coli-produced proteins, Phoxl interacts with SRF to enhance the rate at which SRF binds to and dissociates from the SRE. The enhancing activity resides within the homeodomain of Phox 1 and is shared by closely related homeodomains of the paired class but not by more distantly related homeodomains. Surprisingly, we could never detect stable ternary compl exes composed of SRF, Phoxl, and the SRE using bacterially produced proteins.

Here we show that novel SRF/Phoxl complexes can be formed in HeLa extracts, which suggests that other cellular proteins may be required to promote complex formation. Using a biochemical approach, we have purified, characterized, and cloned the encoding gene for a protein that interacts with Phoxl and SRF and promotes the for- 
mation of this complex. The encoded protein, called SPIN (SRF-Phoxl Interacting protein), has multiple activities, including the ability to bind specifical ly to multi ple sequences in the c-fos promoter and to act cooperatively with Phoxl and SRF to impart serum-inducible expression to a c-fos-driven reporter gene. The observation that this protein is identical to the transcription factor TFII-I (A.L. Roy, H. Du, P.D. Gregor, C.D. N ovina, E. Martinez, and R.G. Roeder, in prep.), which interacts with the basal transcription machinery, suggests that SPIN / TFII-I acts by coordinating the formation of a multiprotein complex at the c-fos promoter and linking specific signal responsive activation complexes to the general transcription machinery (Roy et al. 1991; ManzanoWinkler et al. 1996).

\section{Results}

Novel Phoxl-dependent SRF/SRE complexes are formed in HeLa extracts

Previously, we found that E. coli-produced Phox1 and SRF interact to enhance the rate at which SRF binds to the SRE (Grueneberg et al. 1992). Furthermore, Phox1 promotes serum stimulation of an SRE-containing reporter gene in HeLa cells, suggesting that SRF and Phox 1 interact functionally on the SRE in vivo (Grueneberg et al. 1995). Surprisingly, however, using purified recombinant proteins, we were never able to detect stabl eternary complexes containing SRF, Phox 1 , and the SRE in vitro. To determine whether Phox 1 could form stable complexes with endogenous SRF from HeLa cells, transfection experiments were performed using either the fulllength Phox 1 expression pl asmid or a plasmid expressing an 80-amino-acid fragment of Phoxl that includes the homeodomain. Transfected cells were starved for serum for $24 \mathrm{hr}$, whole-cell extracts were prepared, and mobility-shift assays were performed. To maximize the detection of any high-molecular-weight complexes, the mobility-shift reactions were analyzed on $3.5 \%$ polyacrylamide gels.

Figure 1 shows that expression of the full-length Phoxl protein led to a slight reduction in mobility of the endogenous SRF/SRE complex in Hela extracts (lanes 2,11 ), compared to the empty expression plasmid (lanes 1,10 ) and the smaller homeodomain fragment (lanes 3,12). This observation suggests that overexpression of Phoxl in HeLa cells can lead to the formation of a novel complex on the SRE. That the mobility of the SRF/SRE complex was unaffected by the homeodomain fragment suggests either that this fragment is too small to change the mobility of the complex or that regions outside the homeodomain are required for stable complex formation with SRF.

To confirm that this novel complex contains SRF, we performed additional assays using a monoclonal antibody against SRF (lanes 7-9). Addition of the SRF antibody supershifted both the standard SRF/SRE binary complex (lane 7) and the novel Phoxl-dependent complex (lane 8), suggesting that SRF was present in the

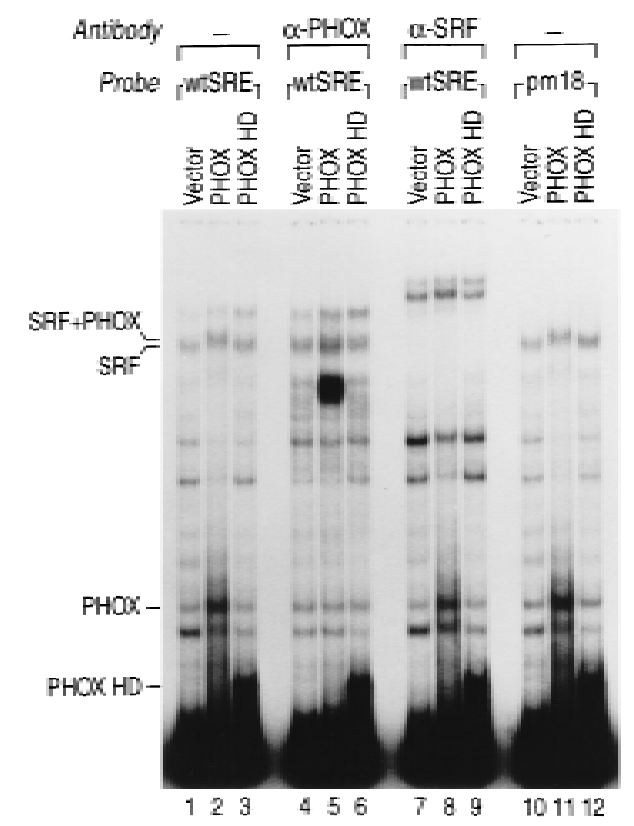

Figure 1. Formation of a novel Phoxl-dependent SRF/SRE complex in HeLa cells. Mobility-shift assay measuring SRF/ SRE interactions from HeLa cell extracts in the presence of exogenous Phox1. Lanes 1-9 utilize the wild-type SRE probe; lanes 10-12 ulitize the Elk-1 mutant probe (pm18; Graham and Gilman 1991). (Lanes $1,4,7,10$ ) Cells are transfected with an empty expression plasmid; (lanes $2,5,8,11$ ) cells are transfected with an expression plasmid producing the full-length Phox 1 protein; (lanes 3,6,9,12) cells are transfected with an expression plasmid producing a truncated Phox 1 protein, containing the homeodomain. Lanes 4-6 were incubated with a Phox1 monoclonal antibody; lanes 7-9 were incubated with an SRF monoclonal antibody.

novel complex. In contrast, monoclonal antibody to Phox 1 abolished the formation of the novel complex and restored the SRF/SRE compl ex seen in control cel Is (lane 5). Despite its inhibitory effect on the novel SRF complex, the Phox 1 antibody enhanced and supershifted the Phox1/SRE binary complex (dark band, lane 5). This observation suggests that formation of this novel complex requires Phoxl surfaces distinct from those required for DNA binding. We conclude that Phoxl is required for formation of this novel SRF-containing complex, although we cannot be certain that it is actually present in this complex.

The response of the c-fos SRE to mitogen-activated protein kinase (MAPK) signals requires a family of Ets domain proteins, termed ternary complex factors, which bind cooperatively with SRF to an adjacent Ets site (Shaw et al. 1989; Dalton and T reisman 1992; Gille et al. 1992; Hipskind et al. 1991; M arais et al. 1993). This ternary complex can be seen immediately above the SRF/ SRE complex in Figure 1, lanes 1-9. We found previously that Phoxl can promote the recruitment of the ternary complex factor Elk-1 to the SRE in vivo (Grueneberg et al. 1995). Consistent with this observation, this ternary 
complex is also shifted in the presence of Phox1 (lane 2). Formation of the ternary complex can be abolished by nucleotide substitutions in the Ets site (Iane 10). Using this probe, the shifting of SRF/SRE complex in the presence of Phox 1 could still be seen (lane 11). Thus, expression of Phoxl promotes the formation of two novel SRFcontaining complexes-one that contains an Elk1-like factor and one that does not.

Because we had never observed such complexes previously using purified SRF and Phoxl, we infer that either (1) SRF and/or Phox1 undergo post-translational modifications in HeLa cells that are required for complex formation, or (2) an additional protein in HeLa cell extracts is required for complex formation. Because SRF and Phox1 produced in rabbit reticulocyte lysates, which are generally competent for most post-translational modifications, also fail to form stable complexes (data not shown), we favor the hypothesis that a third protein is involved.

Purification of a HeLa cell protein that interacts with bacterially produced SRF and Phoxl

We used conventional chromatographic methods to identify a potential cofactor for SRF and Phoxl in HeLa cell extracts. The purification scheme is shown in Figure 2A. After each purification step, fractions were monitored for their ability to promote the formation of a novel complex in the presence of E. coli-produced Phoxl and SRF. Figure 2B shows that the addition of Q-Sepharose fractions 16-20 al tered the mobility of the protein-DN A complex obtained with bacterially produced SRF in the presence of Phox1 (lanes 12,16,20). The same fractions do not have a significant effect on the mobility of SRF alone (lanes $11,15,19)$ or Phox1 al one (lanes $10,14,18)$. Thus, as in crude Hela extracts, formation of the novel complex requires both SRF and Phoxl. Because the SRF and Phoxl proteins used in this experiment were produced in $\mathrm{E}$. coli, we conclude that a distinct protein present in HeLa extracts is required for the formation of stable SRF/Phox 1 compl exes. Furthermore, these observations suggest that the activity in the Q-Sepharose fractions is the same as that detected in the crude extracts of transfected HeLa cells.

Interestingly, these fractions also contained a protein with intrinsic DN A-binding activity that recognized the SRE-containing probe (lanes 9,13,17,21). Thus, these fractions contain both an SRE-binding activity and an activity that promotes the formation of higher-order SRF-containing complexes on the SRE.

To visualize the protein(s) responsible for the supershifting and DNA-binding activities, the Q-Sepharose fractions were analyzed by SDS-PAGE (Fig. 2C). The same Q-Sepharose fractions (I anes 4-8) that exhi bited supershifting and DNA-binding activities contained a predominant protein with apparent relative molecular mass $\left(\mathrm{M}_{\mathrm{r}}\right.$ ) of $120 \mathrm{kD}$. This protein (p120) was most abundant in fractions 19-21 (lanes 5-7). To confirm that this band correlates with the SRF/Phoxl-interacting activity, we examined its ability to interact directly with SRF and
Phox1 in the absence of added DNA. For these experiments we employed Q-Sepharose fraction 22, in which the amount of p120 is relatively low, enabling the other proteins in the fractions to serve as specificity controls. We incubated fraction 22 with glutathione S-transferase (GST) fusion proteins carrying the Phoxl homeodomain or the core domain of SRF. Figure 2D shows that p120 was selectively retained on both GST-Phox1 and GSTSRF beads, relative to other proteins in the fraction (lanes 5 and 6, respectively). In contrast, a control GST fusion protein, containing the $\mathrm{SH} 2$ domain of phospholipase C- $\gamma$ (PLC $\gamma$ ) (Rhee 1991), failed to bind p120 (lane 7).

Although p120 was the major protein retained on the GST -Phoxl and GST-SRF beads, other minor bands can be seen in these lanes. To rule out these proteins as candidates for the supershifting activity, we repeated this experiment with Q-Sepharose fraction 20, which is much more highly enriched for both p120 (see Fig. 2C, lane 6) and supershifting activity (see Fig. 2B, lane 20). If any of these minor bands were responsible for this activity, they should again be present in the GST-Phox 1 and GST-SRF eluate. However, only p120 was detectably retained from fraction 20 on GST-Phoxl and GST-SRF beads (data not shown). Thus, we provisionally conclude that p120 is responsible for the supershifting activity in the Q-Sepharose fractions.

To determine whether the DNA-binding activity in this fraction copurified with the supershifting activity, eluted material from the GST-Phoxl beads and GSTPLC $\gamma$ beads was assayed for its ability to bind an SRE probe. Figure 2E shows that the GST-Phox1 eluted material contai ned an activity that recognized the SRE (Iane 1), whereas the GST-PLC $\gamma$ el uate did not (lane 2). Taken together, these results suggest that p120 interacts directly with SRF and Phoxl in the absence of DNA and that p120 or a tightly associated protein has intrinsic DN A-binding activity. We provisionally refer to p120 as SPIN.

\section{SPIN binds to multiple sites in the c-fos promoter}

To determine whether SPIN specifically binds to the SRE, we performed DN ase I footprinting analysis on a probe containing c-fos promoter sequences from -362 to -266 . Surprisingly, we observed two footprints on this probe, one on the SRE and the other on a site $25 \mathrm{bp}$ upstream (data not shown). The upstream site corre sponds to the c-sis/platelet-derived growth factor (PDGF)-inducible element (SIE), which cooperates with the SRE in the c-fos promoter to mediate induction by polypeptide growth factors, serum, and TPA ( $\mathrm{Hill}$ and Treisman 1995). The SIE binds a protein SIF (c-sis-inducible factor), which is composed of Stat 1 and Stat3 (Hayes et al. 1987; Wagner et al. 1990; Fu and Zhang 1993; Sadowski and Gilman 1993; Sadowski et al. 1993). To confirm that SPIN binds specifically to these sites and to map the sites at nucleotide resolution, we performed dimethylsulfate (DMS) interference analysis. Figure 3A shows a DM S interference assay of Q-Sepharose-purified 
A
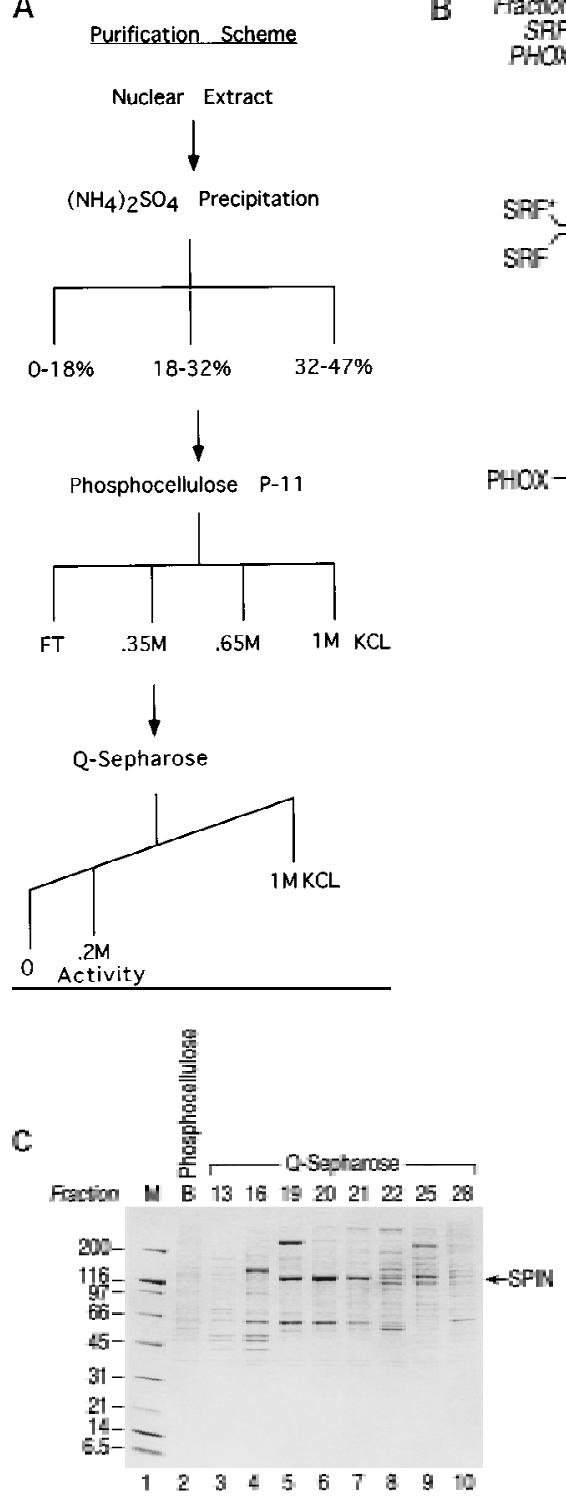

B Fraction $=---, F T-16-18-20-20-22-24$

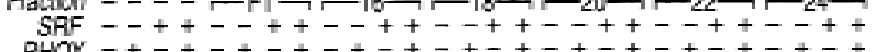

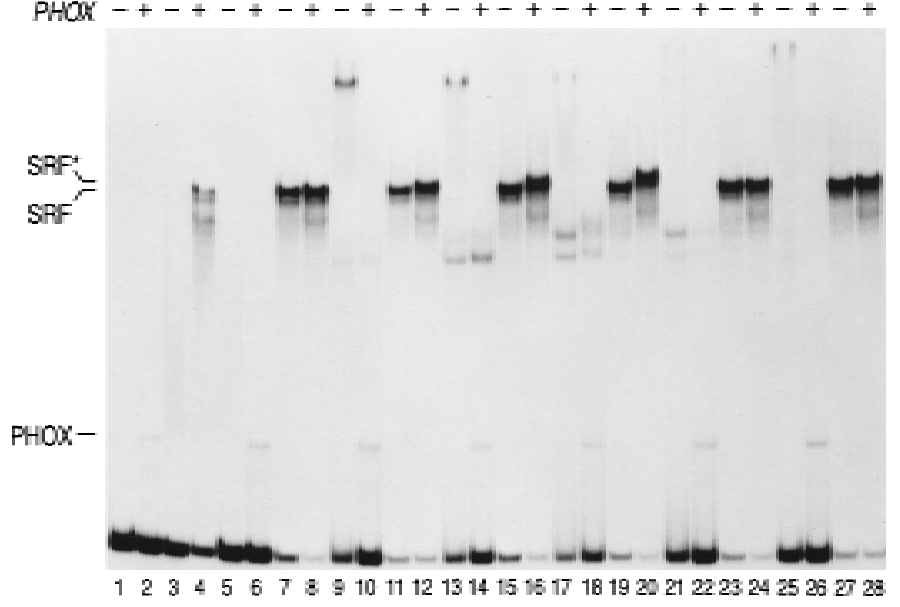

$1234567 \Xi \equiv 10111213141516171819202122282425262728$

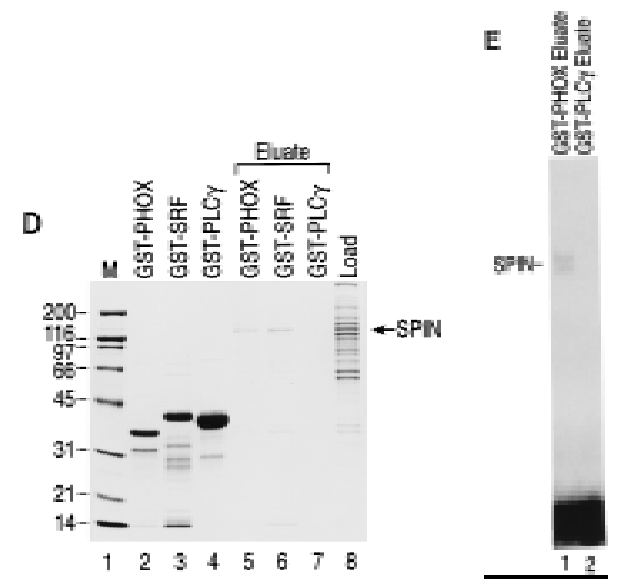

Figure 2. Identification of a human protein required for the formation of the novel Phox1-dependent SRF/SRE complex. (A) Purification scheme for identifying a HeLa cell protein that supershifts SRF/SRE complexes in the presence of Phox1. (B) HeLa cell protein peaks in fractions 16-20 to supershift E. coli-produced SRF in the presence of Phox1. M obility-shift assays using E. coli-produced Phox1 in the absence (lane 2) and presence (lanes 6,10,14,18,22,26) of HeLa fractions; E. coli produced SRF in the absence (lane 3) and presence (lanes 7,11,15,19,23,27) of HeLa fractions; and both proteins together in the absence (lane 4) and presence (lanes 8,12,16,20,24,28) of HeLa fractions on the wild-type SRE probe. (C) A $120 \mathrm{kD}$ protein copurifies with the Phox1-dependent SRF/SRE supershift. The protein fractions were monitored by $4 \%-20 \%$ SDS-PAGE reveal ing an abundant $120 \mathrm{kD}$ protein that correlates with the supershifting activity. SDS-PAGE analysis shows phosphocellulose B fraction (lane 2) and Q-Sepharose fractions (lanes 3-10), visualized by coomassie blue. (D) A $120 \mathrm{kD}$ protein from fraction 22 interacts directly with GST-Phox1, GST-SRF, but not with GST-PLC $\gamma$. The GST fusion proteins, including GST-Phox1, GST-SRF, and GST-PLC $\gamma$, were incubated with gl utathione-agarose beads and washed several times to remove the background lysate proteins. The GST-Phox1, GST-SRF, and GST-PLC $\gamma$ proteins (lanes 2,3, and 4, respectively) were incubated with $20 \mu \mathrm{l}$ of fraction 22 (lane 8) and washed several times, and the bound proteins were eluted off at $600 \mathrm{mM} \mathrm{KCl}$. The 120 KD protein was eluted off the Phoxl beads (lane 5), the SRF beads (lane 6), but not the PLC $\gamma$ beads (lane 7). The proteins were detected by $12 \%$ SDS-PAGE and stained with coomassie blue. (E) Purifed $120 \mathrm{kD}$ protein binds to an SRE-containing probe. M obility-shift assay monitoring DN A-binding activity in the GST-Phoxl eluate (lane 1) and the PLC $\gamma$ eluate (lane 2) using a 31-bp oligonucleotide probe containing the wild-type SRE.

SPIN on the coding and noncoding stands of each probe. The wild-type SIE probe (lanes 1-4) contains a wild-type SIE and a mutant SRE, whereas the wild-type SRE probe (lanes 5-8) contains a wild-type SRE and a mutant SIE.
Mutant probes were used to confine binding to a single site on each probe. Consistent with the DN ase I footprinting assay, the methylated guanines that interfered with SPIN-DNA interactions corresponded to residues 
Figure 3. SPIN binds to multiple sites in the c-fos promoter. (A) DMS interference assay showing the methylated guanines that interfere with SPIN binding (0). The wild-type SIE probe (lanes 1-4) contains a wild-type SIE and a mutant SRE; and the wild-type SRE probe (lanes 5-8) contains a wild-type SRE and a mutant SIE. The interference pattern is shown for the upper (coding) and lower (noncoding) strands of c-fos promoter sequence -362 to -266 . (Lanes 1,3,5,7) The absence of fraction 19 [(UB) unbound]; (lanes 2,4,6,8) the presence of fraction 19 [(B) bound]. The data are summarized at the bottom. (B) Competition analysis of SPIN. Mobility-shift assays were performed using fraction 19 and a 31-bp ol igonucl eoti de probe containing the SIE site. The reactions contain a 100-fold (lanes 2-5), 200-fold (lanes 7-10), or 400-fold (lanes 12-15) molar excess of cold competitor oligonucleotides containing the wild-type SIE (Ianes 2,7,12), m67 SIE (Ianes 3,8,13), wild-type SRE (lanes $4,9,14)$, or pm12 SRE (lanes 5,10,15) binding sites.
A

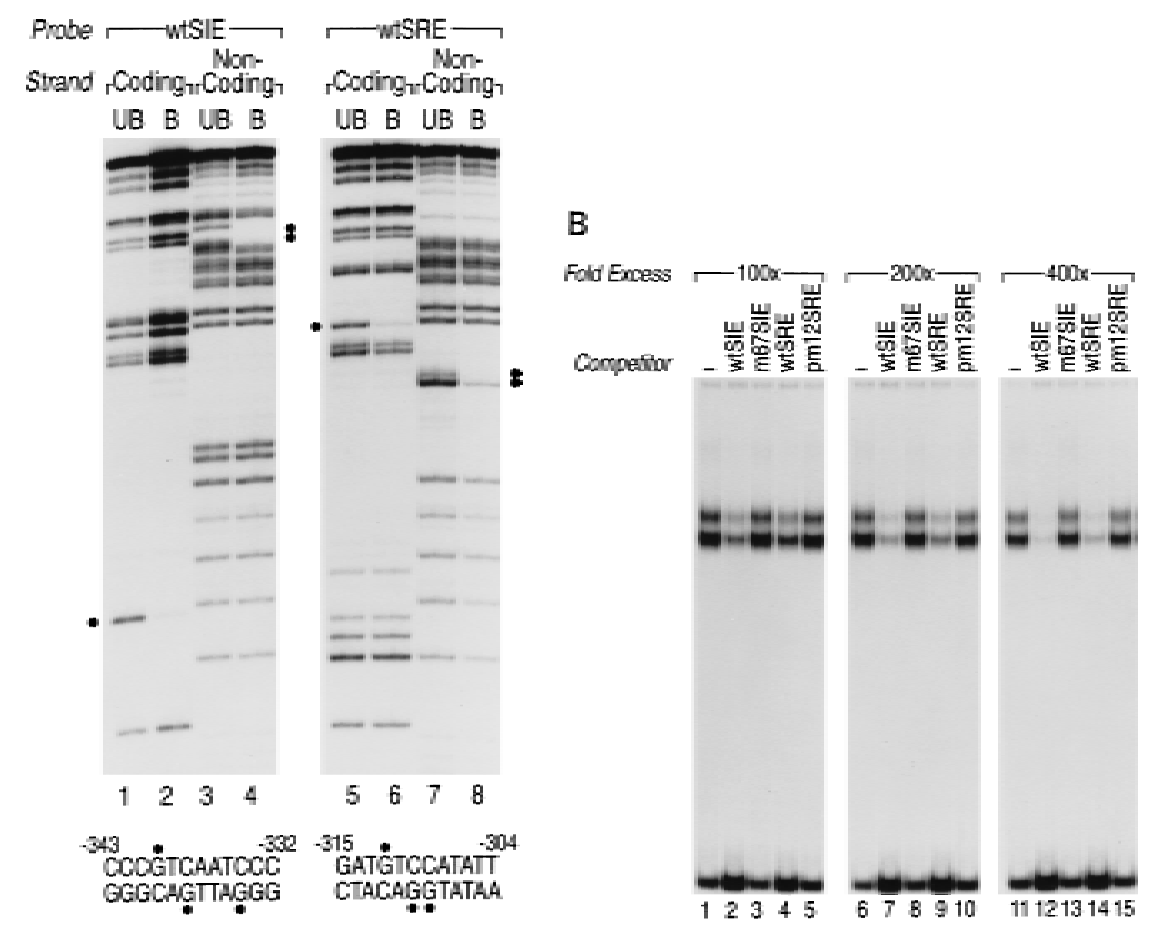

in the vicinity of the SIE (lanes 2,4 ) and the SRE (lanes $6,8)$. The two sequences bound by SPIN are clearly related: 5'-GTCAAT-3' at the SIE and 5'-GTCCAT-3' at the SRE, where boldface type indicates the single discrepant position. These results show that SPIN is a sequence-specific DNA-binding protein that recognizes sequences in the vicinity of the SIE and the SRE in the c-fos promoter.

To determine whether SPIN binds to these sites with similar affinity, radiolabeled SPIN/SIE complexes were incubated with cold competitor oligonucleotides containing either SIE or SRE sequences. Figure 3B shows that SPIN bound to the SIE probe (lanes $1,6,11$ ) in the absence of unlabeled competitor. Binding of SPIN was competed by the addition of excess unlabeled wild-type SIE (lanes 2,7,12) or wild-type SRE (lanes 4,9,14) but not by mutant SIE (lanes $3,8,13$ ) or mutant SRE (lanes $5,10,15)$ oligonucleotides. These results suggest that SPIN binds specifically and with similar affinity to both the SIE and the SRE in the c-fos promoter.

\section{Isolation of CDNA clones encoding SPIN}

SPIN was purified by the fractionation scheme shown in Figure 2A, separated by SDS-PAGE, and transferred to polyvinyl difluoride (PVDF) membrane. The membrane was stained with amido black, and the $120 \mathrm{kD}$ band was excised. A 22-amino-acid peptide was generated by digestion with cyanogen bromide and sequenced by Edman degradation. The peptide sequence was used to design a 56-nucleotide guess-mer and run against the Genbank expressed sequence tag (EST) database (Lathe 1985). A match was found and nucleotides in the wobble position of the guess-mer were modified to generate a perfectly homol ogous hybridization probe. The probe was used to screen a HeLa cell $\lambda$ gt11 cDN A library, and 40 positive clones were obtai ned after three rounds of screening. The cDN A s i solated from three separate clones contained the same open reading frame (ORF) but differed in the 3'untranslated region. The sequence encodes a 957-aminoacid protein with a predicted $M_{r}$ of 108 kD. The 22-aminoacid peptide isolated from the purified protein was present in the predicted sequence of the encoded protein (underlined in Fig. 4A). There were no significant matches to any proteins in the database and no recognizableDNA-binding domain, suggesting that SPIN uses a novel structure for DN A recognition. The most significant feature of the sequence is an 88-amino-acid motif that is present six times, as four highly conserved repeats and two less well-conserved repeats (underlined in Fig. 4A).

SPIN is identical in sequence to the initiator binding protein TFII-I (A.L. Roy, H. Du, P.D. Gregor, C.D. Novina, E. Martinez, and R.G. Roeder, in prep.). Like the activity purified from HeLa cells, TFII-I binds specifically to the initiator Inr elements and activates transcription of a TATA ${ }^{-} / \mathrm{Inr} r^{+}$promoter in vitro. To determine whether Q-Sepharose-purified SPIN also binds to initiator elements, we performed a mobility-shift assay on a probe containing the Inr from the adenovirus major late (AdML) promoter (Manzano-Winkler et al. 1996). Figure $4 \mathrm{~B}$ shows that SPIN bound to the AdML Inr element (lane 5) in addition to the SIE (lane 1) and the SRE (lane 3). However, under our conditions, competition analysis showed that SPIN binds to the SIE and SRE with 


\section{A}

MAQVAMSTLPVEDEESSESRMVVTFLMSALESMCKELAKSKAEVACIAVYETDVFVVGTE RGRAFVNTRKDFQKDFVKYCVEEEEKAAEMHKMKSTTQANRMSVDAVETETLRKTVEDYF CFCYOKALGKSTVVPVPYEKMLRDOSAVVVOGLEEGVAFKHPENYDLATLKWILENKAG SFIIKRPFLEPKKHVGGRVMVTDADRSILSPGGSCGP IKVKTEPTEDSG ISLEMAAVTVK EESEDPDYYQYNIQGSHHSSEGNEGTEMEVPAEDDDYSPPSKRPKANEL POPPVPEPANA GKRKVREFNFFKWNARITDLRKOVEELFERKYAOAIKAKGPVTIPYPLFOSHVEDLYVEG LPEGIPERRESTYGIPRLERILLAKERIRFVIKKHELLNSTREDLQLDKPASGVKEEWXZ RITKLRKMVDOLFCKKFAEALGSTEAKAVPYOKFEAHPNDLYVEGLPENIPFRSPSWYGI PRLEK 1 IQVGNRIKFVIKRPELLTHSTTEVTOPRTNTPVKEDWNVRITKLRKOVEEIENL KFAQALGLTEAVKVFYPVFESNPEFLYVEGL PEGI RERSETWFG IRRLERIVRGSLKKIKF VVKKPELVISYLPPGMASKINTKALQSPKRPRSPGSNSKVPEIEVTVEGPNANNPPQTSAV RTPTQTNGSNVPFKPRGREF SFEAWNAK ITDLKOKVENLFNEKCGEALCLKOAVKVIFAL FESEPEDFYVEGLPEGVPFRRPSTFGIPRLEKILRNKAKIKFIIKKPEMFETAIKESTSS KSPPRKINSS PNVNTTAASGVEDLNI IOVTT PDDDNERLSKVVEKAROLREOVNDLFSRKFC EAIGMGEPVKVPYRKITLNPGCVVVDGMPPGVSFKAPSYLEISSTMRRILDSAEEIKETVI RPFPGLVINNQLVDQSESEGPVIQSEAEPSQLEVPATEEIKETDGSSQIKQEPDPTW

slightly higher affinity than to the AdML Inr element (data not shown).

\section{The TFII-I protein contains SPIN activities}

To further establish the relationship between SPIN and TFII-I, we analyzed the SPIN-containing Q-Sepharose fractions with an antiserum raised against a synthetic peptide derived from TFII-I (C.D. N ovina, V. Cheriyath, and A.L. Roy, in prep.). The resulting blot showed that the SPIN /TFII-I antiserum recognized a $120 \mathrm{kD}$ band in the same Q-Sepharose fractions that contained the supershifting and DNA-binding activities of SPIN (Fig. 5A, lanes 3-7; cf. to Fig. 2C).

To determine whether the SPIN /TFII-I antibody recognized the SIE/SRE DN A-binding activity in Q-Sepharose-purified SPIN, we added the antibody to a mobilityshift assay. Figure 5B shows that the SPIN / SIE complex was abolished by the SPIN /TFII-I antibody (lane 5) but not by preimmune serum (lane 4). The effect of the antibody is specific for SPIN / SIE complexes because it did not abolish binding of the Phoxl homeodomain to the SRE (lane 8). Interpretation of this experiment is somewhat complicated by the presence of contaminating protease activity in the SPIN /TFII-I antiserum, which partially cleaves all of the control proteins we have tested, creating novel high-mobility complexes on mobilityshift gels, as seen in lanes 5 and 8 . Nevertheless, the antiserum specifically and reproducibly abolished SPIN DNA-binding activity at concentrations at which it had no effect on DNA-binding activity of control proteins.

To further establish that the cloned SPIN /TFII-I gene encodes a protein with the same DNA-binding specificity as the SPIN activity in HeLa cells, mobility-shift assays were performed with recombinant protein expressed in mammalian cells. The full-length protein was produced in COS cells as a GST fusion under the control of the EF-1 $\alpha$ promoter (Tanaka et al. 1995). The GSTSPIN protein is easily distinguished from endogenous

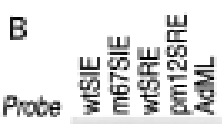

Figure 4. The SPIN CDNA and the TFII-I CDNA are identical; SPIN binds to an Inr element. (A) Clones encoding the SPIN protein were isolated from a human HeLa cell cDN A library. The SPIN ORF predicts a peptide of 957 amino acids that identifies a protein of $108 \mathrm{kD}$ in its unmodified state. The peptide generated by Edman degradation is underlined and labeled; the six repeats are underlined and al so labeled. (B) N ative SPIN protein from HeLa cells binds to the AdML Inr element. Mobility-shift assays were performed using fraction 19 and 31-bp oligonucleotide probes containing the wild-type SIE (lane 1), M67 SIE, (lane 2), wild-type SRE (lane 3), pm12 SRE (lane 4), or AdML (lane 5).
SPIN by its increased molecular mass (C.D. N ovina, V. Cheriyath, and A.L. Roy, in prep.). Figure 5C shows that purified GST -SPIN binds to the C-fos SIE site (lane 1) and less strongly to the mutant site (lane 2 ). These results confirm that the isolated SPIN cDNA encodes the 120 $\mathrm{kD}$ sequence-specific DN A-binding protein and that this activity also resides in TFII-I.

To establish that recombinant SPIN also interacts with Phoxl and SRF, we transfected COS cells with a mammalian expression plasmid producing GST-SPIN and either a Phoxl or an SRF expression plasmid. $\mathrm{N}$ ucl ear extracts from transfected cells were incubated with SPIN/TFII-I antiserum, and immunoprecipitated complexes were probed with an antibody against epitope tags present at the amino termini of Phoxl and SRF. Figure 5D shows that full-length Phoxl coprecipitated with SPIN, as indicated by the presence of a 33-kD Phox 1 band (lane 2) not seen in extracts of cells transfected with the empty expression plasmid (lane 1). Both full-length SRF (lane 7) and the SRF core domain (lane 8) also coprecipitated with SPIN. Thus, SPIN interacts with both Phoxl and SRF in nuclear extracts.

To assess the specificity of this interaction, we also examined three Phox 1 mutants carrying amino acid substitutions in solvent-exposed side chains of homeodomain helices one and two. These residues have been shown previously to be required for the activity of Phox 1 at the SRE in vivo but not for binding of Phoxl to the SRE in vitro, suggesting that they participate in proteinprotein interactions required for in vivo activity (Grueneberg et al. 1995). One of the three Phoxl mutants, ED, which carries substitutions in gl utamate and aspartate residues on homeodomain helix two, failed to coprecipitate with SPIN (lane 3), despite being expressed at levels equal to the other proteins (data not shown). Thus, recombinant SPIN interacts specifically with both Phox1 and SRF, and its interaction with Phoxl requires surface-exposed amino acids previously implicated in the activity of Phoxl at the SRE in vivo. 


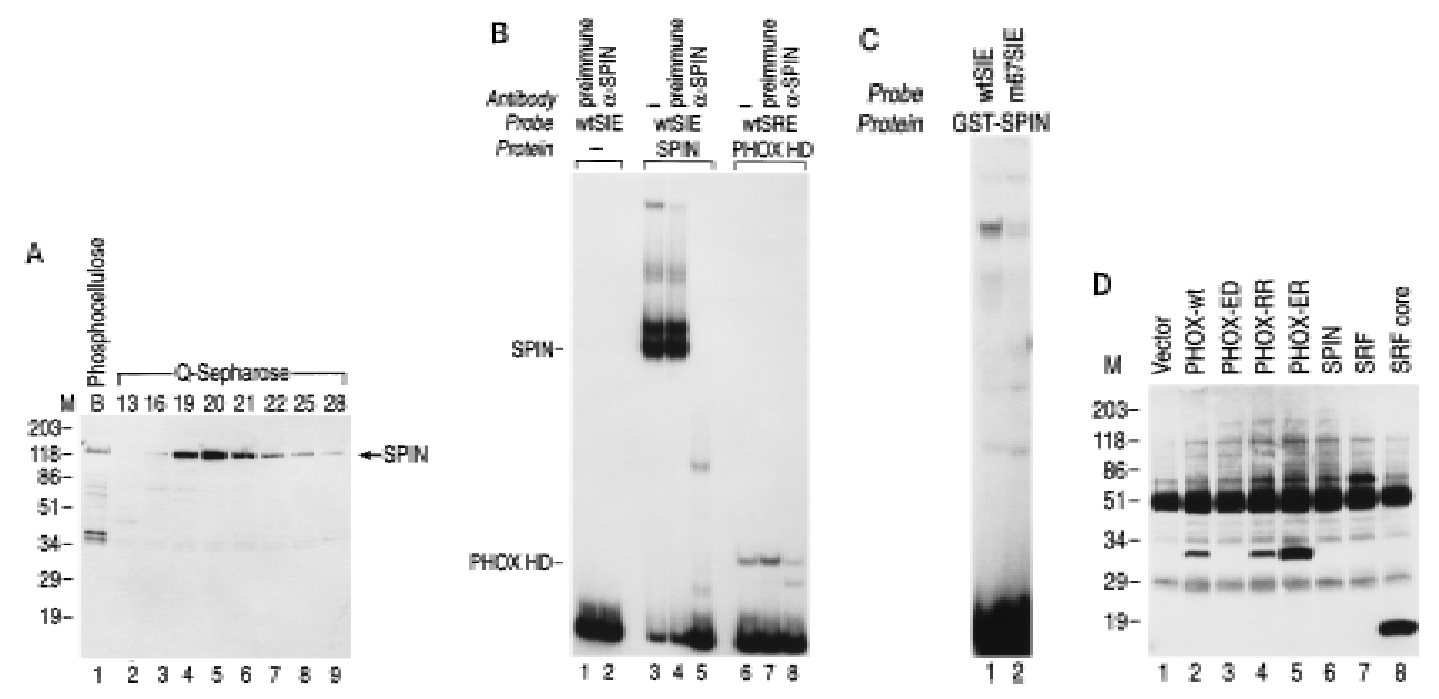

Figure 5. TFII-I protein contains SPIN activity. (A) SPIN /TFII-I antisera recognize the $120 \mathrm{kD}$ protein in HeLa cells. The same protein fractions from Fig. 2C were separated by $12 \%$ SDS-PAGE, transferred to PVDF membrane, immunoblotted with a polycl onal antibody to SPIN /TFII-I, and visualized by chemiluminescence. The $120 \mathrm{kD}$ immunoreactive band is present in phosphocellulose B fraction (lane 1) and a subset of Q-Sepharose fractions (Ianes 2-9). (B) SPIN /TFII-I antisera disrupt the SPIN / SIE complex. A mobility-shift assay monitoring SPIN protein (fraction 19) binding to a 31-bp oligonucleotide probe containing the SIE site (lanes 3-5), or E. coli-produced Phox1 homeodomain binding to a 31-bp oligonucleotide probe containing the SRE (lanes 6-8). Lanes 5 and 8 were incubated with SPIN /TFII-I antibody; I lanes 4 and 7 with prei mmune serum; Ianes 3 and 6 represent the no-antibody control. The SPIN /TFII-I antibody (Iane 1 ) and the preimmune serum (Iane 2) have no effect on probe al one. (C) Recombinant GST-SPIN binds to the same sequence as the native protein from HeLa cells. Mobility-shift assays monitoring the binding of recombinant GST-SPIN protein, produced in mammalian cells and purified to homogeneity (C.D. N ovina, V. Cheriyath, and A.L. Roy, in prep.), to the 31-bp ol igonucleotide probes containing the wild-type SIE site (lane 1) or the m67 SIE site (lane 2). (D) Transfected Phoxl and SRF can be immunoprecipitated from COS cells with SPIN /TFII-I antibodies. COS cells were cotransfected with an expression plasmid producing GST-SPIN and expression plasmids producing the wild-type Phoxl protein (lane 2), mutant Phoxl protein substituting amino acids ED to AA at positions 32 and 33 of the homeodomain (lane 3), mutant Phoxl protein substituting amino acids RR to AA at positions 36 and 37 of the homeodomain (lane 4), mutant Phox 1 protein substituting amino acids ER to AA at positions 21 and 22 of the homeodomain (lane 5), GST-SPIN (Iane 6), SRF (lane 7), SRF core containing the DN A-binding domain (lane 8), or with an empty expression plasmid (lane 1). Transfected extracts were immunoprecipitated with SPIN/TFII-I antibody, analyzed by $12 \%$ SDS-PAGE, and visualized with the monoclonal antibody 12CA5, which recognizes the HA epitope located at the amino terminus of each protein.

SPIN /TFII-I cooperates with Phox1 to impart serumresponsive transcription to the c-fos SRE

Our biochemical data suggest that SPIN mediates the formation of productive SRF/Phoxl complexes on sequences such as the c-fos SRE. To test this hypothesis in vivo, we introduced expressi on vectors producing Phox 1 and/or SPIN into HeLa cells together with a chloramphenicol acetyl transferase (CAT) reporter gene under the control of a basal c-fos promoter and a singl e copy of the c-fos SRE. Figure 6 shows that, as shown previously (Grueneberg et al. 1995), expression of Phoxl in HeLa cells leads to a 17-fold enhancement of serum-induced reporter gene activity (lane 2). Expression of SPIN had no effect on this activity at these concentrations, suggesting that SPIN on its own was incapable of promoting the formation of a signal responsive complex on the SRE (lane 1). However, the combination of Phoxl and SPIN was significantly more effective than Phoxl al one, suggesting that SPIN promotes the formation of Phoxl-dependent signal responsive compl exes on the SRE (lane 3). This effect was abolished on a reporter gene containing mutations that prevent SRF binding, suggesting indi-

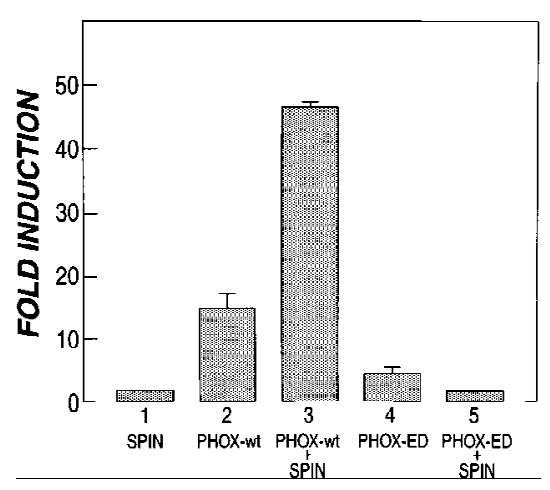

Figure 6. SPIN interacts with SRF and Phoxl in mammalian cells and potentiates the transcriptional response. HeLa cells were cotransfected with expression plasmids producing the GST-SPIN protein (lane 1), wild-type Phox1 protein (lane 2), wild-type Phoxl and GST-SPIN (lane 3), mutant Phoxl substituting amino acids ED to AA at positions 32 and 33 of the homeodomain (lane 4), and Phox-ED and GST-SPIN (lane 5). Extracts were prepared from the cells $48 \mathrm{hr}$ after transfection and assayed for CAT activity. The final numbers represent fold induction where activated transcription is divided by the basal transcription resulting from the blank expression plasmid. 
rectly that SRF is also required for the formation of these complexes.

In contrast to wild-type Phoxl, the mutant Phoxl derivative $E D$, which fails to bind SPIN, was unable to activate the SRE in vivo (Fig. 6, bar 4; see also Grueneberg et al. 1995). Furthermore, the activity of the ED mutant was not enhanced by coexpression of SPIN (lane 5). Thus, a direct interaction between Phox 1 and SPIN is apparently required for SPIN to exert its enhancing activity on serum inducibility of the SRE in vivo. We conclude that SPIN promotes the interaction of multicomponent signal responsive complexes composed of Phox1 and SRF.

\section{Discussion}

We have been studying the interaction of the human homeodomain protein Phox1 with SRF. Phox1 was originally identified in a yeast screen through its ability to interact functionally with the yeast SRF homolog MCM 1 (Grueneberg et al. 1992). We found that Phox1 exhibited a similar functional interaction with SRF in that it permitted certain SRF-binding sites to respond to incoming signal transduction information in mammalian cells (Grueneberg et al. 1995). These observations led us to propose that one aspect of the cell identity function harbored by many homeodomains may be the ability to endow cell-specific genes with the capacity to respond to extracellular signals and that this activity may be a key component of the cell identity function.

One difficulty with this hypothesis was that welacked information on the biochemical organization of these putative SRF/homeodomain complexes. In particular, we could not reconstitute from purified proteins any stable SRF/Phoxl complexes that would be expected to mediate the activity we observed in transfected cells. Although Phoxl could influence the kinetics of DNA binding by SRF in vitro, strongly suggesting that these proteins interact directly, the interaction appeared to be highly transient in the absence of any other cofactors.

The idea that a missing cofactor might be required for stable complex formation was first suggested by our observation that extracts from yeast expressing Phoxl generated an MCM1-containing mobility-shift complex with distinct mobility from the complex generated by MCM 1 al one (D.A. Grueneberg, unpubl.). Again, however, this complex could not be reconstituted with purified proteins, and preliminary reconstitution experiments with fractionated yeast extracts suggested that an additional activity was required to promote the formation of this novel complex. Here, we have purified a similar activity from human cells. We find that this protein has multiple activities, including the ability to interact with both SRF and Phox1, to bind specific sequences in the c-fos promoter, and to cooperate with Phoxl and SRF to mediate serum-inducible transcriptional activity at the SRE. Furthermore, we have discovered that this protein is identical to the transcription factor and initiator-binding protein TFII-I, suggesting that it may have a broader role in the organization of multiprotein transcription factor complexes, particularly at developmentally regulated genes.

\section{Interaction of SPIN/TFII-I with SRF and Phox1}

Three distinct lines of evidence suggest that SPIN interacts with both SRF and Phox1. First, we can detect direct and independent interactions of SPIN with SRF and Phoxl using two experimental approaches. N ative SPIN is selectively bound from complex protein fractions by GST fusions of both SRF and Phoxl. And both SRF and Phoxl can be coimmunoprecipitated with SPIN following cotransfection in COS cells. Second, the novel SRFcontaining complex is formed only when SRF, Phoxl, and SPIN are all present. Third, SPIN significantly enhances the ability of Phoxl to impart serum-responsive transcriptional activity to the c-fos SRE. This activity requires amino acid residues in Phoxl that are also required for the direct interaction of Phoxl with SPIN, and it also requires an intact SRF binding site. Thus, we believe that formation of this active transcription complex requires the interaction of SPIN with both SRF and Phox1. Whether that interaction is simultaneous or sequential, or stable or transient, remains unclear.

The interaction of SPIN with Phoxl appears to require surfaces of the Phoxl homeodomain not directly involved in DNA binding. This idea is supported by the observation that a monoclonal antibody to Phoxl abolishes formation of the SPIN -dependent complex but does not affect DNA binding by Phoxl. Furthermore, amino acid substitutions on the solvent-exposed surface of homeodomain helix two, previously shown not to affect DN A binding (Grueneberg et al. 1995), abolish both the interaction of Phoxl with SPIN in the coimmunoprecipitation assay and the ability of SPIN to augment the transcriptional activity of Phoxl at the SRE in vivo.

It remains difficult to envision the precise physical organization of the novel SRF/SRE complex that we observe on mobility-shift gels. Clearly, the reduction in mobility of this complex relative to the putative SRF/ SRE binary complex is much less than would be expected for the incorporation of a $120-k D$ protein. When mobility-shift assays are performed using a c-fos promoter probe containing both the SIE and the SRE, which allows independent co-occupancy of the probe by SPIN and SRF, respectively, a complex of considerably sl ower mobility is observed (data not shown). This complex is clearly different from the one that forms on an isolated SRE in the presence of SPIN, SRF, and Phoxl. This observation could mean that the action of SPIN is transient-either catalytic in a classic sense or merely unstable on the mobility-shift gels. An alternative hypothesis is that SPIN, SRF, and Phoxl are all present in the novel complex observed on the mobility-shift gels, but that the effect of this cooperative interaction is to dramatically compact the complex, increasing its mobility in the gel. A third possibility stems from the observation that SPIN binds only to one-half of the SRE dyad; in joining this complex, SPIN may displace one subunit of an SRF dimer. 
Interaction of SPIN/TFII-I with DNA

As we purified SPIN activity, we noted the copurification of a DNA-binding activity that recognized the c-fos SRE. The purified protein and recombinant SPIN exhibit high-affinity binding to two critical regulatory elements of the c-fos promoter-the SRE, which mediates the response of c-fos to multiple signal transduction pathways, and the SIE, which is a binding site for STAT (signal transducer and activator of transcription) proteins (Gilman 1988; Treisman 1990; Fü and Zhang 1993; Sadowski et al. 1993; Zhong et al. 1994; Hill and Treisman 1995). Thetwo bound sequences are closely related and are contained within the Inr consensus sequence T / CT /CANT / AT/CT/C (Javahery et al. 1994). SPIN, as purified from HeLa cells in our hands, also binds to the AdML Inr sequence, al though it does so with noticeably lower affinity relative to the SRE and SIE sites.

Inspection of the promoter sequence of c-fos reveals at least two other sequences that match the binding consensus for SPIN. One of these sites is located at the transcriptional initiation site of the gene, and the other is located just downstream of the CAMP responsive element. Although these sites have not been tested directly for binding, this observation suggests that SPIN may make multiple contacts with the c-fos promoter. Whether these sites are bound independently by monomeric SPIN or coordinately by a higher-order multimer is not known. But the presence of multiple helix-loophelix-like motifs in the TFII-I sequence suggests that multimeric forms of the protein may be common. It is of particular interest that a SPIN -binding site is closely associated with each of the major signal-responsive elements in the c-fos promoter.

Organization of a multiprotein complex at the c-fos promoter

SPIN can potentially interact with many sites in the c-fos promoter and with both upstream activator proteins and basal transcription factors. If even a subset of these interactions can be performed simultaneously by a single SPIN protein or multimer, it is likely that SPIN imposes a specific and restricted architecture on the cfos promoter. This architecture may be critical to the unusual demands placed on this promoter. The c-fos gene is poised for rapid and high-magnitude transcriptional response to extracellular signals (Greenberg and Ziff 1984; Greenberg et al. 1985). The gene reaches maximal transcriptional activity within minutes of external stimulation (Greenberg and Ziff 1984; Kruijer et al. 1984; Greenberg et al. 1985). The promoter receives multiple signaling inputs through a set of transcription factors that are independently modulated by distinct signaling pathways (Graham and Gilman 1991; M arais et al. 1993; Hill et al. 1994). Furthermore, it is evident that the c-fos promoter can integrate incoming signaling information, as suggested, for example, by the observation that a promoter in which both the SRE and the SIE are intact responds more robustly than a promoter in which one of the elements is missing (Hill and Treisman 1995). In this specific example, SPIN binding in the vicinity of both sites could coordinate communication between these signaling elements and relay integrated signaling information to the basal transcriptional machinery. Furthermore, the observation that SPIN is itself phosphorylated on serine, threonine, and tyrosine residues (C.D. N ovina, V. Cheriyath, and A.L. Roy, in prep.) and its recently reported association with the protein-tyrosine kinase Btk (Yang and Desiderio 1997) suggests additional mechanisms through which this protein may participate directly in the processing of signal transduction information into a transcriptional response.

\section{Materials and methods}

Mammalian expression plasmids

For transient transfection assays in HeLa and COS cells, fulllength Phox1 amino acids 1-217, Phoxl homeodomain amino acids 58-138, full-length SRF amino acids 1-508, and SRF core amino acid 92-222 were expressed from the cytomegalovirus (CM V)-based vector pCGN (Tanaka and Herr 1990). The Phox1 mutant constructs were described previously (Grueneberg et al. 1995). The pCGN vector contains the influenza virus hemagglutinin (HA) epitope tag inserted at the amino terminus of each effector plasmid (recognized by the 12CA 5 antibody; Field et al. 1988). The full-length GST-SPIN (same as GST-TFII-I) containing amino acids 1-957 was expressed from the EF-1 $\alpha$ vector pEBGI (C.D. Novina, V. Cheriyath, and A.L. Roy, in prep.).

Transient transfection assay

HeLa cells were grown in Dulbecco's modified Eagle medium (DM EM) supplemented with $10 \%$ fetal bovine serum (FBS). All transfections were performed using calcium phosphate coprecipitation as described (Grueneberg et al. 1995). Cells were seeded on $10-\mathrm{cm}^{2}$ plates and transfected at $30 \%$ confluence. For the CAT assay, transfection cocktails contained $0.6 \mu \mathrm{g}$ of wildtype Phox1, a mutant Phoxl derivative ED, or GST-SPIN expression plasmids along with $2 \mu \mathrm{g}$ of the reporter plasmid containing a single c-fos SRE upstream of a c-fos-CAT fusion gene containing fos sequences from -56 to +109 . All other transfection cocktails contained $4.8 \mu \mathrm{g}$ of Phoxl and SRF expression plasmids and $3.2 \mu \mathrm{g}$ of the GST-SPIN expression plasmid. In all cases, the total DNA concentration was adjusted to $20 \mu \mathrm{g}$ with pUC119 DNA. The cells were incubated with the transfection precipitates for $16 \mathrm{hr}$, washed three times with phosphate-buffered saline (PBS), and incubated for $24 \mathrm{hr}$ in DMEM containing $15 \%$ FBS. For the mobility-shift assays, HeLa cells were harvested and resuspended in $70 \mu \mathrm{l}$ of IP buffer [0.1\% N P-40, $25 \mathrm{~mm}$ HEPES at pH 7.9, $400 \mathrm{~mm} \mathrm{NaCl}, 1 \mathrm{~mm}$ EDTA, 1 mM DTT, 0.5 $\mathrm{mm}$ phenylmethylsulfonyl fluoride (PMSF)]. For the coimmunoprecipitation assay, COS cells were harvested and resuspended in $200 \mu \mathrm{l}$ of hypotonic buffer. For the CAT assay, HeLa cells were harvested and resuspended in $100 \mu \mathrm{l}$ of PBS. The CAT assay was done as described previously (Gorman et al. 1982).

\section{E. coli expression plasmids}

For E. coli expression, the full-length SRF protein was expressed from pT 7f1.A (Kuret et al. 1988), a derivative of pET 11c (Studier et al. 1990). SRF was used as a crude E. coli lysate. All other proteins were produced as GST fusions from the vector $\mathrm{pET}$ GST, including Phoxl amino acids 5-217, Phox1-homeodomain 
amino acids 58-138, and PLC $\gamma$ amino acids 547-659. The GST fusion proteins were purified on glutathione-agarose (Sigma) (Smith and Johnson 1988) and the GST moiety was cleaved off the GST-Phox1 and GST-Phox1-homeodomain proteins with thrombin (Sigma) (Gearing et al. 1989).

\section{Mobility-shift and DMS interference assays}

For the mobility-shift assay using transfected cells, $10-\mathrm{cm}^{2}$ plates were harvested, resuspended in $70 \mu \mathrm{l}$ of IP buffer, and sonicated twice with 2 -sec pulses. The extracts were centrifuged for $20 \mathrm{~min}$ to remove cell debris, and $2 \mu \mathrm{l}$ of the supernatant was used in DN A-binding assays. Assays contained $10 \mathrm{~mm}$ Tris (pH 7.5), $50 \mathrm{~mm} \mathrm{NaCl}, 1 \mathrm{~mm}$ dithiothreitol (DTT), 5\% glycerol, $50 \mu \mathrm{g} / \mathrm{ml}$ of poly[d(G-C)]-[d(G-C)]. Assays containing the bacterially produced proteins and the purified fractions are identical to the above, except they contain $75 \mathrm{~mm} \mathrm{NaCl}, 15$ $\mu \mathrm{g} / \mathrm{ml}$ of poly[d(G-C)]-[d(G-C)], $5 \mu \mathrm{g}$ of bovine serum albumin (BSA), and $3 \mathrm{~mm} \mathrm{MgCl}_{2}$. Reactions were incubated in the absence of probe for $10 \mathrm{~min}$ at room temperature. Following the addition of probe $(20,000 \mathrm{cpm})$, the reactions were incubated for another $10 \mathrm{~min}$. Analysis was typical ly on a $5 \%$ polyacrylamide gel (39:1 acrylamide/ bis ratio) in 0.5×TBE (Tris borate EDTA) buffer, except for Figure 1, which required a 3.5\% polyacrylamide gel.

Mobility-shift probes used in Figures 1 and 2B contained the SRE sequence derived from the $-561 \times$ SRE fos-CAT fusion gene, where the SRE is positioned at -56 in the mouse c-fos promoter and contains sequences from -56 to +109 (Berkowitz et al. 1989; Gilman et al. 1986). Probes were synthesized in a $P C R$ reaction using ${ }^{32} \mathrm{P}$-end-label ed $\mathrm{T} 3$ and +23 primers, which flank the SRE sequence. All other mobility-shift probes were generated by annealing 31-bp oligonucleotides: the wild-type c-fos SRE 5'-A GCTTACAGGATGTCCATATTAGGACATCTG-3' (Gilman et al. 1988); the pm12 SRE 5'-AGCTTACAGGATGTGGATATTACCACATCTG-3' (Gilman et al. 1988); the wild-type c-fos SIE 5'-AGCTGCCGGCGAGCAGTTCCCGTCAATCCCTC-3' (Hayes et al. 1987); the m67 SIE 5'-AGCTGCCGGCGAGCATTTCCCGTAAATCCCTC-3' (Wagner et al. 1990); and the AdML Inr 5'-AGCTTACAGGATGTCTCACACTCTCTACATCTG-3' (Manzano-Winkler et al. 1996). Probes were labeled by a Klenow reaction with all four $[\alpha-$ ${ }^{32} \mathrm{P}$ ]deoxynucleotide triphosphates and gel purified before use.

Probes used for the DM S interference assay incorporated c-fos promoter sequence -362 to -266 , which were radiolabeled on either strand in reactions containing one ${ }^{32} \mathrm{P}$-end-label ed primer and one cold primer. The DMS interference protocol was described previously (Attar and Gilman 1992).

\section{Purification of SPIN from HeLa extracts}

HeLa cells were grown to $10^{6}$ cells/ml in spinner flasks containing Joklik's modified Eagle's medium supplemented with $5 \%$ calf serum. For the purification of SPIN, HeLa cell nuclear extracts were prepared according to Dignam et al. (1983). Approximately 0.5 liter of nuclear extract was selectively precipitated using ammonium sulfate $\left[\left(\mathrm{N} \mathrm{H}_{3}\right)_{2} \mathrm{SO}_{4}\right]$ from $18 \%$ to $32 \%$. The precipitate was resuspended in $100 \mathrm{ml}$ of buffer $D[20 \mathrm{~mm}$ HEPES (pH 7.9), 0.2 mm EDTA, 20\% glycerol, 3 mm DTT, 0.5 $\mathrm{mm}$ PMSF] containing $90 \mathrm{mM} \mathrm{KCl}$ and was subsequently dialyzed against the same buffer for $3 \mathrm{hr}$ at $4^{\circ} \mathrm{C}$. The $18 \%-32 \%$ $\left(\mathrm{N} \mathrm{H}_{3}\right)_{2} \mathrm{SO}_{4}$-precipitated material (1.1 gram protein) was loaded on a P11 (Whatman) phosphocellulose column (8 mg of protein/ $\mathrm{ml}$ of packed resin). The column was washed with 3 column volumes of buffer $\mathrm{D}+100 \mathrm{~mm} \mathrm{KCl}$ (P11-A fraction) and then step eluted with 3 column volumes of buffer $D+350 \mathrm{~mm} \mathrm{KCl}$
(P11-B fraction), followed by 3 column volumes of buffer D +500 mM KCl (P11-C fraction) and buffer D + 1 M KCl (P11-D fraction). The P11-B fraction contained SPIN activity and was diluted with 2 volumes of buffer Q0 [20 mM HEPES (pH 7.9), 0.5 mM EDTA, 5\% glycerol, 0.1\% Tween-20, 1 mM DTT, $0.5 \mathrm{~mm}$ PMSF, $1 \mathrm{~mm}$ sodium metabisulfite, $1 \mathrm{~mm}$ benzamidine, $1 \mu \mathrm{M}$ pepstatin $\mathrm{A}$ ] to reduce the $\mathrm{KCl}$ concentration and was loaded onto a M ono-Q HR 10/10 column (Pharmacia). The column was washed with $40 \mathrm{ml}$ of buffer Q100 (Q0 containing $100 \mathrm{~mm} \mathrm{KCl}$ ) and the bound material was eluted with an 80-ml linear gradient of $100 \mathrm{~mm}$ to $1 \mathrm{M} \mathrm{KCl}$ in buffer Q. Fractions were collected (BMQ fractions, $1 \mathrm{ml}$ each) and were tested for SPIN activity by mobility-shift assay. The peak of SPIN activity eluted between 180 and $250 \mathrm{~mm} \mathrm{KCl}$ (fractions BMQ 16-BM Q 20).

\section{Generation of SPIN peptides}

M ono-Q fractions 19 and 20 were combined and resuspended in $2 \times \mathrm{SDS}$ sample buffer, heated to $90^{\circ} \mathrm{C}$ for $5 \mathrm{~min}$, and subjected to $10 \%$ SDS-PAGE. The polypeptides were transferred to PVDF membrane by wet transfer in a buffer containing $25 \mathrm{~mm}$ Tris base, $192 \mathrm{~mm}$ glycine, and 20\% methanol. The membrane was stained with amido black to visualize the $120 \mathrm{kD}$ band, which was excised and treated with $150 \mathrm{~mm}$ cyanogen bromide (CN Br) in $70 \%$ formic acid for $5 \mathrm{hr}$ at $55^{\circ} \mathrm{C}$. The resulting peptides were analyzed using as ABI 494 Procise sequencer revealing a strong proline residue at cycle three. The $\mathrm{CN} \mathrm{Br}$ digestion was repeated, and the sequencer was stopped at cycle two exposing a peptide with a proline residue at position 3 from the amino terminus. The membrane was subsequently treated with o-phthalaldehyde (OPA), blocking all CNBr-generated peptides except the proline-containing peptide, and sequencing commenced from the proline at position 3 out to position 22 (Brauer et al. 1984).

\section{CDNA library screening}

The peptide generated by microsequencing was converted into a guess-mer probe and searched against the Genbank EST data base to generate an exact match probe (Lathe 1985). The oligonucleotide probe 5'-GATGATGATTATTCTCCACCGTCTAAGAGACCAAAGGCCAATGAGCTACCGCAGCC-3' was used to screen an oligo(dT) plus random-primed $\lambda$ gt 11 CDNA library (Clontech), derived from human HeLa cells. Approximately 300,000 plaques were lifted onto Hybond-N membrane (A mersham) and probed with the 5 '-end-label ed ol igonucleotide probe. The filters were soaked for $4 \mathrm{hr}$ at $58^{\circ} \mathrm{C}$ in prehybridization solution 2 (Clontech) containing $6 \times$ SSPE, $5 \times$ Denhardt's solution, $0.25 \% \mathrm{SDS}$, and $100 \mu \mathrm{g} / \mathrm{ml}$ of herring sperm DNA. Hybridization was carried out in the same solution; however, the radiolabeled probe was included and the reaction was extended for another $16 \mathrm{hr}$. Filters were rinsed in $2 \times$ SSC with $0.05 \%$ SDS for $1 \mathrm{hr}$ at $37^{\circ} \mathrm{C}$, followed by a more stringent wash at $58^{\circ} \mathrm{C}$ for $15 \mathrm{~min}$. After three rounds of successive screening, 40 positive clones were obtained and the DNA isolated from three revealing 3.0-, 3.4-, and 4.0-kb cDN As. All three cDN As were amplified in a PCR reaction using $\lambda$ gt $115^{\prime}$ and $3^{\prime}$ insert amplifying primers (Clontech) and cloned into a TA cloning vector (Invitrogen). Two of the CDN A clones were sequenced on both strands to generate a putative ORF, which, when compared to the sequence of TFII-I (A.L. Roy, H. Du, P.D. Gregor, C.D. N ovina, E. Martinez, and R.G. Roeder, in prep.), revealed our sequence was missing 90 amino acids from the amino terminus.

Generation of TFII-I antibodies and immunoblotting

Polyclonal antibodies were raised against the synthetic peptide: GKRKVREFNFEWNARITDLR generated from the deduced 
amino acid sequence of the TFII-I cDNA (C.D. Novina, V. Cheriyath, and A.L. Roy, in prep.). For the coimmunoprecipitation assay, the SPIN / TFII-I antibodies were purified using protein A-Sepharose, enriching for the IgG fraction.

All immunoblots were blocked in 5\% BSA/PBS for $1 \mathrm{hr}$ at room temperature and washed three times in Western wash buffer containing $50 \mathrm{~mm}$ Tris (pH 7.5), $150 \mathrm{~mm} \mathrm{~N} \mathrm{aCl}$, and $0.2 \%$ N P-40. The dilution of the primary antibody was typically 1 : 2500 , and the secondary antibody was 1:1500. The primary antibodies, SPIN /TFII-I and 12CA5, and secondary anti-rabbit or anti-mouse horseradish peroxidase conjugate antibodies were incubated in 2.5\% BSA/PBS for $1 \mathrm{hr}$ at room temperature and washed five times in Western wash buffer. The immunoreactive proteins were visualized by chemiluminesence (NEN).

\section{Nuclear extracts and coimmunoprecipitation assay}

For the coimmunoprecipitation assay transfected-COS cells were harvested and resuspended in $200 \mu$ lof hypotonic buffer containing $20 \mathrm{~mm}$ HEPES (pH 7.9), $20 \mathrm{~mm} \mathrm{NaF}, 1 \mathrm{~mm} \mathrm{~N} \mathrm{a} \mathrm{VO}_{4}$, $1 \mathrm{~mm} \mathrm{~N} \mathrm{a} \mathrm{P}_{2} \mathrm{O}_{7}, 0.125 \mu \mathrm{m}$ okadaic acid, $1 \mathrm{~mm}$ EDTA, $1 \mathrm{~mm}$ DTT, $0.5 \mathrm{~mm}$ PMSF, and $1 \mu \mathrm{g} / \mathrm{ml}$ each of leupeptin, aprotinin, and pepstatin (Sadowski and Gilman 1993). The cells were incubated on ice for $15 \mathrm{~min}$ and lysed by five passages through a 25-gauge needle. The nuclei were collected by centrifugation and resuspended in $100 \mu \mathrm{l}$ of the above buffer containing 420 $\mathrm{mm} \mathrm{NaCl}$ and $10 \%$ glycerol, for the extraction of nuclear proteins. For the immunoprecipitation assay, the nuclear extracts were precleared in a reaction containing $50 \mu \mathrm{l}$ of nuclear extract, $350 \mu \mathrm{l}$ of hypotonic buffer, and $50 \mu \mathrm{l}$ of protein A-Sepharose. Following centrifugation to remove the protein A-Sepharose, 7 $\mu \mathrm{l}$ of purified TFII-I antibody was added to the reaction and incubated for $4 \mathrm{hr}$ at $4^{\circ} \mathrm{C}$. The immune complexes were recovered by the addition of $50 \mu \mathrm{l}$ of protein A-Sepharose and washed five times in hypotonic buffer containing $57 \mathrm{~mm} \mathrm{~N} \mathrm{aCl}$ and $0.1 \%$ N P-40. After the final wash, $2 \times$ SDS sample was added, and the beads were heated to $90^{\circ}$ for $5 \mathrm{~min}$, anal yzed by SDS PAGE, and immunoblotted with $12 \mathrm{CA} 5$ antibodies that recognize the $\mathrm{HA}$ epitope fused to the amino terminus of each exogenously produced protein. The immunoreactive proteins were visualized by chemiluminesence.

\section{Acknowledgments}

We are indebted to the Hernandez laboratory for the chromatographic purification of SPIN/TFII-I. We thank Sridar N atesan, Richard Rickles, and Robert Roeder for critically reading the manuscript. We thank Caroline Kannengiesser for her participation in the project. R.W.H. is supported by U.S. Public Health Service grant GM 38810 from the N ational Institutes of Health belonging to Dr. Nouria Hernandez. V.C. and A.L.R. are supported by a grant from the Concern Foundation for Cancer $\mathrm{Re}$ search. These studies were supported by U.S. Public Heal th Service Grant CA 45642 from the $\mathrm{N}$ ational Institutes of Heal th and ARIAD Pharmaceuticals.

The publication costs of this article were defrayed in part by payment of page charges. This article must therefore be hereby marked "advertisement" in accordance with 18 USC section 1734 solely to indicate this fact.

\section{References}

Attar, R.M. and M.Z. Gilman. 1992. Expression cloning of a novel zinc-finger protein that binds to the c-fos serum re sponse element. Mol. Cell. Biol. 12: 2432-2443.
Berkowitz, L.A., K.T. Riabowol, and M.Z. Gilman. 1989. Multiple sequence elements of a single functional class are required for cyclic AMP responsiveness of the mouse c-fos promoter. Mol. Cell. Biol. 9: 4272-4281.

Brauer, A.W., C. Oman, and M.N. M argolies. 1984. Use of ophtal al dehyde to reduce background during automated Edman degradation. Analyt. Biochem. 137: 134-142.

Dalton, S. and R. Treisman. 1992. Characterization of SAP-1, a protein recruited by serum response factor to the c-fos serum response element. Cell 68: 597-612.

Dignam, J.D., R.M. Lebowitz, and R.G. Roeder. 1983. Accurate transcription initiation by RNA polymerase II in a soluble extract from isolated mamalian nuclei. Nucleic Acids Res. 11: 1475-1489.

Field, J.J., Nikawa, D. Broek, B. MacDonald, L. Rodgers, I.A. Wilson, R.A. Lerner, and M. Wigler. 1988. Purification of a RAS-responsive adenylyl cyclase complex from Saccharomyces cerevisiae by use of an epitope addition method. Mol. Cell. Biol. 8: 2159-2165.

Fu, X.Y. and J.J. Zhang. 1993. Transcription factor p91 interacts with the epidermal growth factor receptor and mediates activation of the c-fos gene promoter. Cell 74: 1135-1145.

Gearing, D.P., N.A. Nicola, D. Metcalf, S. Foote, T.A. Willson, N.M. Gough, and R.L. Williams. 1989. Production of leukemia factor in Escherichia coli by a novel procedure and its use in maintaining embryonic stem cells in culture. BioTechnology 7: 1157-1161.

Gille, H.S., D. Andrew, and P.E. Shaw. 1992. Phosphorylation of transcription factor $\mathrm{p} 62^{\mathrm{TCF}}$ by MAP kinase stimulates ternary complex formation at c-fos promoter. Nature 358: 414417.

Gilman, M.Z. 1988. The c-fos serum response el ement responds to protein kinase $C$-dependent and -independent signals but not to cyclic AMP. Genes \& Dev. 2: 394-402.

Gilman, M.Z., R.N. Wilson, and R.A. Weinberg. 1986. Multiple protein-binding sites in the $5^{\prime}$-flanking region regulate $c$-fos expression. Mol. Cell. Biol. 6: 4305-4316.

Gilman, M.Z., L.A. Berkowitz, J.R. Feramisco, B.R. Franza, R.M. Graham, K.T. Riabowol, and W.A. Ryan. 1988. Intracellular mediators of c-fos induction. Cold Spring Harbor Symp. Quant. Biol. 53: 761-767.

Gorman, C.M., L.F. M offat, and B.H. Howard. 1982. Recombinant genomes which express chloramphenicol acetyltransferase in mammalian cells. Mol. Cell. Biol. 2: 1044-1051.

Graham, R. and M.Z. Gilman. 1991. Distinct protein targets for signals acting at the $c$-fos serum response element. Science 251: 189-192.

Greenberg, M.E. and E.B. Ziff. 1984. Stimulation of 3T 3 cells induces transcription of the c-fos proto-oncogene. Nature 311: 433-438.

Greenberg, M .E., L.A. Greene, and E.B. Ziff. 1985. N erve growth factor and epidermal growth factor induce rapid transient changes in proto-oncogene transcription in PC12 cells. J. Biol. Chem. 260: 14101-14110.

Grueneberg, D.A., S. N atesan, C. Alexandre, and M.Z. Gilman. 1992. Human and Drosophila homeodomain protein that enhance the DNA-binding activity of serum response factor. Science 257: 1089-1095.

Grueneberg, D.A., K.J. Simon, K. Brennan, and M.Z. Gilman. 1995. Sequence-specific targeting of nuclear signal transduction pathways by homeodomain proteins. Mol. Cell. Biol. 15: 3318-3326.

Hayes, T.E., A.M. Kitchen, and B.H. Cochran. 1987. Inducible binding of a factor to the c-fos regulatory region. Proc. Natl. Acad. Sci. 84: 1272-1276.

Hill, C.S. and R. Treisman 1995. Differential activation of c-fos 
promoter elements by serum, lysophosphatidic acid, $\mathrm{G}$ proteins and polypeptide growth factors. EMBO J. 14: 50375047.

Hill, C.S., J. Wynne, and R. Treisman. 1994. Serum-regulated transcription by serum response factor (SRF): A novel role for the DN A-binding domain. EMBO J. 13: 5421-5432.

Hipskind, R.A., V.N. Rao, C.F.G. Mueller, E.S.P. Reddy, and A. N ordheim. 1991. Ets-related protein Elk-1 is homologous to the c-fos regulatory factor p62 ${ }^{\mathrm{TCF}}$. Nature 354: 531-534.

Javahery, R.K., A. Khachi, K. Lo, B. Zenzie-Gregory, and S.T. Smale. 1994. DNA sequence requirements for transcriptional initiator activity in mammalian cells. Mol. Cell. Biol. 14: 116-127.

Kruijer, W., J.A. Cooper, T. Hunter, and I.M. Verma. 1984. PDGF induces rapid but transient expression of the c-fos gene. Nature 312: 711-716.

Kuret, J., K.E. Johnson, C. Nicolette, and M.J. Zoller. 1988. Mutagenesis of the regulatory subunit of yeast CAM P-dependent protein kinase: isolation of site-directed mutants with altered binding affinity for catalytic subunit. J. Biol. Chem. 263: 9149-9154.

Lathe, R. 1985. Synthetic oligonucleotide probes deduced from amino acid sequence data: Theoretical and practical considerations. J. Mol. Biol. 183: 1-12.

Manzano-Winkler, B., C.D. N ovina, and A.L. Roy. 1996. TFII-I is required for transcription of the naturally TATA-less but initiator-containing V $\beta$ promoter. J. Biol. Chem. 271: 1207612081.

M arais, R., J. Wynne, and R. Treisman. 1993. The SRF accessory protein Elk-1 contains a growth factor-regulated transcriptional activation domain. Cell 73: 381-393.

Rhee, S.G. 1991. Inositol phospholipid-specific phospholipase $C:$ Interaction of the $\gamma 1$ isoform with tyrosine kinase. Trends Biochem. Sci. 16: 297-301.

Roy, A.L., M. M eisterernst, P. Pognonec, and R.G. Roeder. 1991. Cooperative interaction of an initiator-binding transcription initiation factor and the helix-loop-helix activator USF. Nature 354: 245-248.

Sadowski, H.B. and M.Z. Gilman. 1993. Cell-free activation of a DNA-binding protein by epidermal growth factor. Nature 362: 79-83.

Sadowski, H.B., K. Shuai, J.E. Darnell, Jr., and M.Z. Gilman. 1993. A common nuclear signal transduction pathway activated by growth factor and cytokine receptors. Science 261: 1739-1744.

Shaw, P.E., H. Schroter, and A. N ordheim. 1989. The ability of a ternary complex to form over the serum response el ement correlates with serum inducibility of the human c-fos promoter. Cell 56: 563-572.

Smith, D.B. and K.S. Johnson. 1988. Single-step purification of polypeptides expressed in Escherichia coli as fusions with glutathione-S-transferase. Gene 67: 31-40.

Studier, F.W., A.H. Rosenberg, J.J. Dunn, and J.W. Dubendorff. 1990. U se of T7 RNA polymerase to direct the expression of cloned genes. Methods Enzymol. 185: 60-89.

Tanaka, M. and W. Herr. 1990. Differential transcriptional activation by oct- 1 and oct-2: Interdependent activation domains induce oct-2 phosphorylation. Cell 60: 375-386.

Tanaka, M., R. Gupta, and B.J. Mayer. 1995. Differential inhibition of signalling pathways by dominant-negative $\mathrm{SH} 2$ / SH3 adapter proteins. Mol. Cell. Biol. 15: 6829-6837.

Treisman, R. 1990. The SRE: A growth factor responsive transcriptional regulator. In Seminars in cancer biology transcription factors, differentiation and cancer (ed. N. Jones), pp. 47-58. Saunders Scientific Publications, London, UK.

Wagner, B.J., T.E. Hayes, C.J. Hoban, and B.H. Cochran. 1990.
The SIF binding element confers sis/PDGF inducibility onto the c-fos promoter. EMBO J. 9: 4477-4484.

Yang, W. and S. Desiderio. 1997. BA P-135, a target for Bruton's tyrosine kinase in response to $B$ cell receptor engagement. Proc. Natl. Acad. Sci. 94: 604-609.

Zhong, Z., Z. Wen, and J.E. Darnell, Jr. 1994. Stat3: A STAT family member activated by tyrosine phosphorylation in response to epi dermal growth factor and interleukin-6. Science 264: 95-98. 


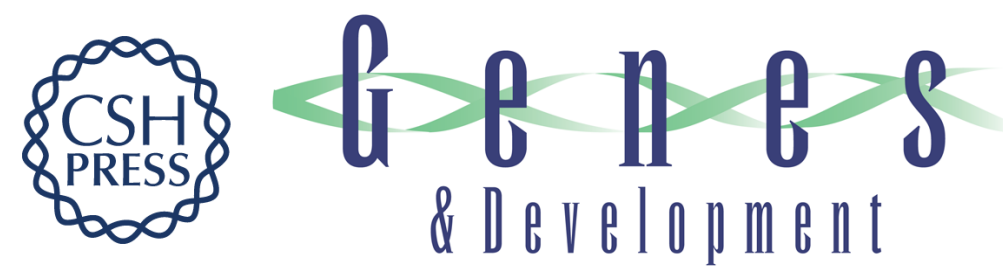

\section{A multifunctional DNA-binding protein that promotes the formation of serum response factor/homeodomain complexes: identity to TFII-I}

Dorre A. Grueneberg, R. William Henry, Andrew Brauer, et al.

Genes Dev. 1997, 11:

Access the most recent version at doi:10.1101/gad.11.19.2482

References

This article cites 37 articles, 18 of which can be accessed free at:

http://genesdev.cshlp.org/content/11/19/2482.full.html\#ref-list-1

License

Email Alerting

Receive free email alerts when new articles cite this article - sign up in the box at the top

Service right corner of the article or click here.

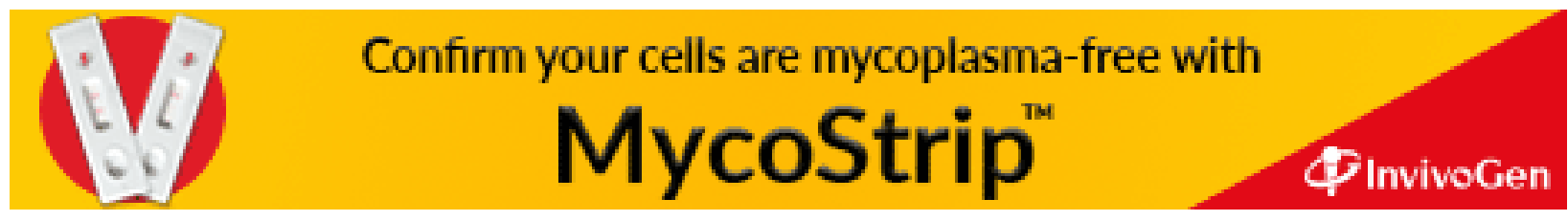

